\title{
Understanding on The Management of Sport Injuries Through Sport Massage and Rice Method for Ipsi Pencaksilat Athletes in Pekalongan District
}

\author{
Mega Widya Putri ${ }^{1}$, Gilang Nuari Panggraita ${ }^{2}$, Idah Tresnowati ${ }^{3}$, Ati safitri ${ }^{4}$, Resty Agustryani ${ }^{5}$ \\ 1, 2, 3,4, Muhammadiyah Pekajangan Pekalongan State University \\ ${ }^{5}$ Siliwangi State University \\ Email: 1megawidyaputri@umpp.ac.id, ${ }^{2}$ panggraita@umpp.ac.id, 3idahtersnowati@umpp.ac.id, \\ 4atisafitri@gmail.com, 5restyagustryani@unsil.ac.id \\ d \\ https://doi.org/10.36526/gandrung.v2i2.1316
}

\begin{abstract}
The aimof this The aimofthis community service is to provide knowledge in the field of handling sports injuries through sports massage and the rice method for pencak silat athletes in Pekalongan Regency theoretically and practically in increasing knowledge of handling sports injuries in the field. This community service is carriedout in Pekalongan Regency. The material presented at this seminar is about handling sports injuries through sports massage and therice method. The results of the implementati on of this community service activity are expected to provide knowledge to athletes, especially pencak silat athletes in Pekalongan Regency and can produce quality masseurs for there covery needs of athletes in Pekalongan Regency.
\end{abstract}

Keyword: Sports Injuries, Sport Massage, Rice Method, IPSI Pencak silat Athletes

\section{Pendahuluan}

\section{A. Analisis Situasi}

Sport massage adalah suatu massage(pijat) yang ditujukan kepada semua orang yang sehat. Dalam hal ini tidak mempunyai pengertian bahwa sport massage hanya untuk olahragawan saja, tetapi boleh juga diberikan kepada siapa saja, baik orang tua maupun muda, pria ataupun wanita. Termasuk mereka yang menderita cedera-cedera ringan dapat disembuhkan dengan sport massage.

Dalam dunia olahraga sport massage dapat diterapkan baik sebelum bertanding, saat jeda tanding,dan sesudah olahraga dengan karakteristik khusus sesuai tujuan cabang olahraganya. Secara umum tujuan dari sport massage adalah:

1) Mempelancar peredaran darah, terutama peredaran darah balik ke jantung baik melalui pembuluh darah maupun limfe, sehingga mempercepat proses pembuangan sisa pembakaran dan penyebaran sari makanan ke jaringan.

2) Merangsang persarafan, terutama saraf tepi (perifer), untuk meingkatkan kepekaannya terhadap rangsan. 
3) Meningkatkan tonus dan kekenyalan otot (elastisitas) untuk mempertinggi daya kerjanya.

4) Mempercepat pemulihan kelelahan setelah berolahraga

Sport Massage dapat diterapkan pada seluruh tubuh terutama apabila ditujukan untuk pemulihan kelelahan setelah berolahraga. Massage yang dilakukan sebelum maupun saat jeda olahraga hanya akan menggunakan manipulasi tertentu pada daerah otot tertentu pula yang banyak digunakan untuk berolahraga.

Cedera adalah suatu kerusakan pada struktur atau fungsi tubuh yang dikarenakan suatu paksaan atau tekanan fisik maupun kimiawi. Cedera olahraga adalah cedera pada sistem otot dan rangka tubuh yang disebabkan oleh kegiatan olahraga yang timbul pada saat berlatih, bertanding ataupun setelah berolahraga (Irawan, 2011: 7). Membahas tentang cedera, meskipun itu cedera yang ringan apabila penanganannya tidak tepat akan mempengaruhi penampilan seorang atlet seperti apa yang ditulis oleh Sujandoko (2000: 7), yaitu : Cedera olahraga apabila tidak ditangani dengan cepat dan benar dapat mengakibatkan gangguan atau keterbatasan fisik, baik dalam melakukan aktifitas hidup sehari - harimaupun melakukan aktivitas olahraga yang bersangkutan. Bahkan bagi atlit ini bisa beristirahat yang yang cukup lama atau bahkan bisa meninggalkan sama sekali hobi atau profesinya itu. Oleh sebab itu dalam penanganan cedera olahraga harus dilakukan secara tim yang multidisipliner.

Cedera olahraga ditimbulkan karena olahraga, sehingga dapat menimbulkan cacat, luka dan rusak pada otot atau sendi serta bagian lain dari tubuh" (Andun, 2000: 7). Kegiatan olahraga yang sekarang terus dipacu untuk dikembangkan dan ditingkatkan bukan hanya olahraga prestasi / kompetisi, tetapi juga olahraga untuk kebugaran jasmani secara umum. Kebugaran jasmani tidak hanya punya keuntungan secara pribadi, tetapi juga memberi keuntungan bagi masyarakat dan Negara. Oleh karena itu kegiatan olahraga pada waktu ini semakin mendapat perhatian yang luas. Bersamaan meningkatnya aktivitas keolahragaan tersebut, korban cedera olahragajuga ikut bertambah. Amat disayangkan jika justru karena cedera olahraga tersebut, para pelaku olahraga sulit meningkatkan atau mempertahankan prestasi atau kebugarannya (Sudijandoko, 2000: 7). Cedera olahraga apabila tidak ditangani dengan cepat dan benar dapat mengakibatkan gangguan atau keterbatasan faisik baik dalam melakukan aktivitas hidup sehari - hari maupn melakukan aktivitas olahraga yang bersangkutan. Bahkan bagi atlet ini bisa berarti istirahat yang cukup lama atau bahkan harus meninggalkan sama sekali hobi atau profesinya itu. Oleh sebab itu dalam penanganan cedera harus dilakukan secara tim yang multidisipliner (Sudijandoko, 2000: 7). 2. Penggolongan cedera olahraga Cedera olah raga juga dapat di golongkan atas 2 kelompok besar : 1. Kelompok kerusakan traumatik (traumaticdisruption) misalnya; lecet, lepuh, memar, lebam otot, luka, "strain" otot, "sprain" 
GANDRUNG: Jurnal Pengabdian Kepada Masyarakat ISSN: 2721-6136 (Online)

sendi, dislokasi sendi, patah tulang, trauma pada dada, trauma pada perut, cedera anggota gerak atas dan bawah. 2. Kelompok 'sindroma" penggunaan berlebihan (overusesindromes) yang lebih spesifik berhubungan dengan jenis olahraganya seperti: tenniselbow, golf'selbow, swimer'sshoulder, jumper'sknee, streesfrakture pada tungkai dan kaki (Andun, 2000 : 8). 3. Macam-macam cedera olahraga a. Memar memar adalah pecahnya pembulu darah kecil akibat trauma yang menyebabkan pendarahan menuju kedalam jaringan lunak dibawah kulit dan mengakibatkan perubahan warna kulit. Memar dapat terjadi secara tiba - tiba dan dapat terjadi hingga berbulan - bulan yang menyebabkan rasa sakit, bengkak, dan nyeri. Penyebab memar itu sendiri adalah akibat dari benturan dari benda tumpul sehingga dapat menyebabkan trauma yang berupa memar (irawan, 2011 : 14). Adapun penanganan pada cedera memar adalah sebagai berikut: 1. Kompres denagn es atau air dingin 2. Balut dengan pembalut atau kain dan tekan, tetapi tekanan harus disesuaikan (Rahardjo, 1992:47). b. Spasme atau kram otot Spasme/ kram otot adalah tertariknya atau kontraksi otot yang sangat hebat tanpa disertai adanya relaksasi sehingga mengakibatkan rasa sakit yang sangat hebat. Ada beberapa penyebab terjadinya kram otot yaitu: 1 . Dehidrasi 2. Kadar garam dalam tubuh rendah 3. Kadar karbohidrat rendah 4. Otot dalam keadaan kaku 5. Kurangnya pemanasan (Irawan, 2011 : 14). Penanganan kram otot yang di lakukan sebagai berikut: 1. lakukan peregangan pada otot yang mengalami kejang atau karam. 2. Setelah itu pijat - pijatlah otot tersebut. 3. Bila penyebabnya suhu udara yang tinggi, baringkanlah penderita ditempat yang sejuk dan beri minuman air garam atau oralit (Rahardjo, 1992:53). C. Pingsan Suatu keadaan tidak sadarkan diri seperti orang tertidur pada seseorang akibat sakit, kecelakaan, kekurangan oksigen, kekurangan darah, keracunan, terkejut, lapar, kondisi fisik melemah dan sebagainya (irawan, 2011 : 14-15 ). d. Sprain, sprain adalah cedera yang menyakut cedera pada ligament (jaringan yang menghubungkan tulang dengan tulang) atau kapsul persendihan. Kerusakan kerusakanyang parah pada sendi ini akan menyebabkan sendi menjadi tidak stabil. Gejala yang ditimbulkan adalah rasa sakit, bengkak, memar, ketidakstabilan dan kehilangan kemampuan untuk bergerak. Akan tetapi tanda - tanda dan gejala dapat bervariasi dalam intensitas, tergantung pada beratnya sprain tersebut (Andun, 2000 : 12). e. StrainStrain adalah cedera yang melibatkan peregangan atau robeknya sebuah otot dan tendon (struktur otot). Strain akut terjadi di ujung saat otot menjadi tendon. Menurut Tailor (1997 : 115) cedera akut ditimbulkan karena adanya penekanan melakukan gerakan membelok secara tiba - tiba. Strain biasa terjadi saat berlari ataupun saat melompat dan biasa terjadi pada otot hamstring. Strain adalah cedera yang terjadi secara berkala karena penggunaan berlebihan dan tekanan berulang - ulang dan menghasilkan tendonitis atau perdangan pada tendon (Andun, 2000 : 13 ). f. Patah tulang Patah tulang adalah putusnya tulang yang 
GANDRUNG: Jurnal Pengabdian Kepada Masyarakat ISSN: 2721-6136 (Online)

terjadi ketika adanya tekanan yang berlebihan pada tulang. Dapat terjadi dengan atau tanpa pergeseran tulang (irawan, 2011 : 17). g. Dislokasi Dislokasi adalah terlepasnya kompresi jaringan tulang dari kestuan sendi dislokasi terdapat komponen tulangnya saja yang bergeser atau terlepasnya seluruh komponen tulang dari tempat yang seharusnya. Dislokasi yang sering terjadipadaatet adalah dislokasi sendi bahu dan sendi pinggul atau paha. Gejala yang timbulkan dari dislokasi adalah terlihat jelas dari tempatnya, gerakan menjadi terbatas, terjadi pembengkakan maupun memar dan rasa sakit yang sangat pada waktu digerakkan maupun memberokan beban diatas dislokasi (Irawan, 2011 : 17).

Fenomena yang terjadi di Kabuapaten Pekalongan berdasarkan observasi mengenai pengetahuan tentang recovery khususnya sport massagedan metode rice masih sangat rendah.Sedangkan dalam meraih prestasi atlet harus mampu dalam recovery. Para pelaku olahraga masih mengandalkan massage tradisional. Dimana ada beberapa faktor dalam penanganan cedera olaharaga dengan sport massage baik sebelum dan sesudah pertandingan.

Selain pengetahuan tentang recovery dari sport massage para pelaku olahraga juga kurangnya informasi tentang metode RICE. Metode RICE merupakan suatu metode penanganan cedera dengan menggunakan ice, yang bertujuan untuk mencegah cedera lebih lanjut dan mengurangi rasa nyeri. Dimana $\mathrm{R}=$ rest (istirahat), I=ice (es), C=Compresion (kompres), E=elevation (elevasi).

Melihat situasi seperti ini, tim pelaksana pengabdian kepada masyarakat mempunyai ide, gagasan dan inisiatif untuk melakukan pelatihan kepada atlet, di Kabupaten Pekalongan, yang dimaksudkan dapat menjawab mengenai edukasi dan pengenalan gerakan serta cara menangani cedera olahraga melalui sport massage dan metode rice. Diharapkan ide pengabdian ini dapat memberikan bukti pengembangan yang efektif mengenai peningkatan prestasi olahraga di Kabupaten Pekalongan.Beberapa permasalahan yang dihadapi adalah:Banyaknya cedera olahraga dilapangan yang tidak ditangani dengan benar. Banyaknya atlet kurang pengetahuan tentang penanganan cedera olahraga melalui sport massageda metode rice. Solusi Permasalahan: Memberikan penyuluhan tentang penanganan cedera olahraga melalui sport massage dan metode rice. Buku pengantar/modul yang akan lebih mengefektifkan pelaksanaan penyuluhan.

Luaran yang dihasilkan: Atlet IPSI Kabupaten Pekalongan akan lebih memahami tentang penanganan cedera olahraga dengan menggunakan sport massage dan metode rice.Dapat mengerti tentang penanganan cedera olahraga dengan menggunakan sport massage dan metode rice.

Aktivitas dan target capaian

Volume 2, Number 2, Juli 2021 | 179

Understanding on The Management of Sport Injuries Through Sport Massage and Rice Method for Ipsi

Pencaksilat Athletes in Pekalongan District

Mega Widya Putri, Gilang Nuari Panggraita, Idah Tresnowati, Ati safitri, Resty Agustryani 
GANDRUNG: Jurnal Pengabdian Kepada Masyarakat ISSN: 2721-6136 (Online)

Tabel 1. Tabel Hasil Capaian

\begin{tabular}{|c|c|c|c|c|}
\hline No. & $\begin{array}{l}\text { Aktifitas unt } \\
\text { permasalahan }\end{array}$ & $\begin{array}{l}\text { uk Solusi } \\
\text { mitra }\end{array}$ & $\begin{array}{l}\text { Target capaian yang } \\
\text { diharapkan }\end{array}$ & $\begin{array}{l}\text { Keterlibatan } \\
\text { Mahasiswa }\end{array}$ \\
\hline 1. & $\begin{array}{l}\text { Memberikan } \\
\text { penanganan } \\
\text { olahraga } \\
\text { menggunakan } \\
\text { massage dan m }\end{array}$ & $\begin{array}{r}\text { penyuluhan } \\
\text { cedar } \\
\text { dengan } \\
\text { sport } \\
\text { letode rice. }\end{array}$ & $\begin{array}{l}\text { Atlet } \\
\text { Pekalongan diharakan } \\
\text { dapat mengetahui } \\
\text { bagaimana menagani } \\
\text { cedera dengan } \\
\text { menggunakan sport } \\
\text { massage dan metode } \\
\text { rice dengan baik dan }\end{array}$ & $\begin{array}{l}\text { Membantu } \\
\text { memberikan } \\
\text { penyuluhan kepada } \\
\text { atlet IPSI Kabupaten } \\
\text { Pekalongan. }\end{array}$ \\
\hline 2 & $\begin{array}{l}\text { Mempraktikkan } \\
\text { penanganan } \\
\text { olahraga } \\
\text { menggunakan } \\
\text { massage dan m }\end{array}$ & $\begin{array}{c}\text { cedera } \\
\text { dengan } \\
\text { sport } \\
\text { etode rice }\end{array}$ & $\begin{array}{l}\text { benar. } \\
\text { Atlet IPSI Kabupaten } \\
\text { Pekalongan dihrapkan } \\
\text { dapat menagani cedera } \\
\text { olahraga ketika latihn } \\
\text { dengan sport massage } \\
\text { dan metode rice. }\end{array}$ & $\begin{array}{l}\text { Menjadi probandus } \\
\text { dalam praktik } \\
\text { penanganan cedera } \\
\text { olahraga dengan } \\
\text { menggunakan sport } \\
\text { massage dan } \\
\text { metode rice. }\end{array}$ \\
\hline
\end{tabular}

\section{Metode}

\section{Metode Pendekatan}

Metode pendekatan dalam kegiatan ini menggunakan metode demonstrasi, ceramah dan diskusi. Partisipasi Mitra dalam Pelaksanaan Program: Ikatan Pencak Silat Indonesia (IPSI) adalah induk organisasi resmi pencak silat di Indonesia di bawah naungan KONI (Komite Olahraga Nasional Indonesia). IPSI sebagai wadah pembinaan atlet pencak silat untuk mengikuti pelatihan dan penyuluhan dalam kegiatan ini. Berdasarkan permasalahan mitra IbM, maka kebutuhan dan kesepakatan dengan mitra telah dirumuskan prioritas permasalahan dan solusi yang akan ditawarkan adalah akan dilaksanan program: Pelatihan penagnanan cedera olahraga atlet pencak silat Kabupaten Pekalongan dengan menggunakan sport massage dan metode rice.

Dalam melaksanakan kegiatan IbM ini, pelaksanan membagi menjadi beberapa tahapan atau prosedur kerja, yaitu:

Tahap I

Permohonan ijin kepada Ikatan Pencak Silat Indonesia (IPSI) Kabupaten Pekalongan 
GANDRUNG: Jurnal Pengabdian Kepada Masyarakat ISSN: 2721-6136 (Online)

Tahap II

Penentuan tempat kegiatan

Tahap III

Pelatihan penanganan cedera olahraga atlet pencak silat Kabupaten Pekalongan dengan menggunakan sport massage dan metode rice.

Tahap VI

Melakukan Evaluasi kegiatan

\section{Hasil dan Diskusi}

Kegiatan yang dilaksanakan pada tahap perencanaan adalah dengan melakukan pendekatan kepada IkalatanPencaksilat Indonesia (IPSI) Kabupaten Pekalongan. Kegiatan tersebut dilakukan dengan menyampaikan garis besar usulan kegiatan serta meminta ijin untuk dapat melaksanakan kegiatan, mengonsultasikan tempat dan waktu kegiatan yang sudah di buat atau di susun dengan kegiatan yang akan diadakan. Melakukan informasi kepada seluruh atlet IPSI Kabupaten Pekalongan, dan memberikan informasi tentang akan dilakukan dengan Kerjasama antara IPSI Kabupaten Pekalongan bahwasanya akan diadakan kegiatan pengabdian kepada masyarakat mengenai penanganan cedera olahraga melalui sport massage dan metode rice.

Kegiatan pengabdian masyarakat berupa memberikan edukasi tentang penanganan cedera olahraga melalui sport massage dan metode rice telah berlangsung dengan baik. Hal tersebut dapat dilihat dari sambutan yang baik oleh atlet dan pelatih IPSI Kabupaten Pekalongan dan antusiasme peserta dalam memahami sosialisasi dan edukasi yang telah disusun oleh tim pengabdian. Kegiaitan ini dapat memberikan pengetahuan mengenai penanganan cedera olahraga melalui sport massage dan metode rice pada atlet IPSI Kabupaten Pekalongan.

IPSI Kabupaten Pekalongan menyambut kegiatan tersebut dengan tangan terbuka terkait dengan pelaksanaan pengabdian kepada masyarakat yang telah diadakan. Mulai dari awal dilaksanakan kegiatan dan pendekatan, pihak terkait memberikan tanggapan yang sangat hangat dan bantuan-bantuan yang mendukung terlaksananya kegiatan pengabdian ini.

Berdasarkan hasil memberikan sosialisasi penanganan cedera olahraga melalui sport massage dan metode rice teradap atlet IPSI Kabupaten Pekalongan, tim pengabdian memberikan pemahaman tentang penanganan cedera olahraga melalui sport massage dan metode rice. Hasil dari opservasi menunjukkan bahwa antusiasme, motivasi dan keingintahuan peserta untuk mengetahui halhal yang disampaikan sangat tinggi dibuktikan dengan sikap kooperatif peserta pada saat pengarahan 
GANDRUNG: Jurnal Pengabdian Kepada Masyarakat ISSN: 2721-6136 (Online)

sudah sesuai dengan rencana agar mendapatkan hasil yang diinginkan.
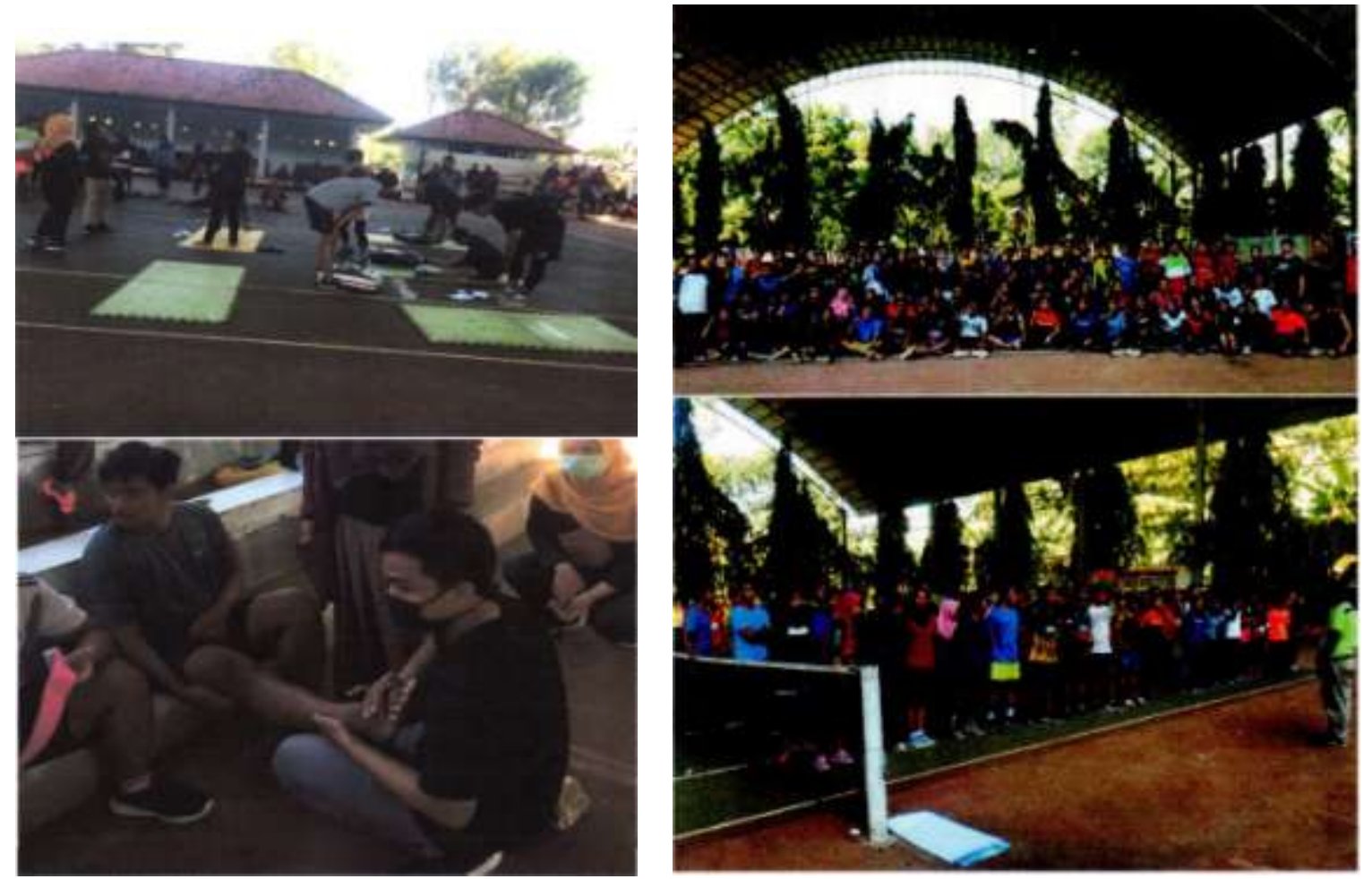

Gambar 1.PraktikPenanganan Cedera Olahraga Melalui Sport Massage Dan Metode Rice

Sesuai dengan yang direncanakan, kegiatan pengabdian masyarakat berupa edukasi penanganan cedera olahraga melalui sport massage dan metode rice, dimaksudkan sebagai sarana pengetahuan atlet IPSI Kabupaten Pekalongan untuk lebih mengetahui tentang penanganan cedera olahraga melalui sport massage dan metode rice.

\section{Kesimpulan}

Refleksi dilakukan terhadap kegiatan yang telah dilaksanakan. Hal ini dilakukan semata-mata untuk mengetahui kekurangan atau kelebihan terhadap kegiatan-kegiatan yang telah dilakukan dalam rangka menetapkan rekomendasi terhadap keberlangsungan atau pengembangan kegiatan berikutnya. Hasil refleksi adalah perlu dilakukan edukasi lebih mendalam mengenai penanganan cedera olahraga melalui sport massage dan metode rice pada atlet IPSI Kabupaten Pekalongan.

\section{Daftar Referensi}

Bentley, Eilean. 2007. Pedoman Menjadi Sehat bagi Orang Sibuk "Pemijatan”. Indonesia edition : 
GANDRUNG: Jurnal Pengabdian Kepada Masyarakat ISSN: 2721-6136 (Online)

1.Karisma Publishing Group 2.Barbara \& Kevin Kunz. 2012. Pijat Refleksi-Sehat Lewat Pijatan Jari. Jakarta : Gaya Favorit Press.

Fondy, Tommy. 2012. Merawat dan Mereposisi Cedera Tubuh. Jakarta.Hall,Guyton. 1996.Fisiologi Kedokteran. Jakarta.

Irawan, R.J. 2011. Pencegahan dan Perawatan Cedera Olahraga.Makalahtidakditerbitkan. Surabaya: IKOR FIK UNESA.

Lilis Komariya, M.Pd. 2010.Modul Pencegahan dan Perawatan Olahraga. Jakarta

Riyadi,Slamet, dkk. 2010. Massage Terapi CideraOlahraga.Yuma Pustaka. Ramdan, Endang. 1982. Olahraga dan Kesehatan. Bandung : Angkasa

Satia Graha, Ali,dkk. 2010. Masase Olahraga (Pendukung Prestasi dan Terapi Cedera Olahraga). Jakarta.

Sudijandoko, Andun. 2000. Perawatan dan Pencegahan Cedera. Jakarta: Departemen Pendidikan dan Kebudayaan. 